\title{
Development of cloned embryos from porcine neural stem cells and amniotic fluid-derived stem cells transfected with enhanced green fluorescence protein gene
}

\author{
Yue-Mao Zheng, Hui-Ying Zhao, Xiao-E Zhao, Fu-Sheng Quan, Song Hua, Xiao-Ying He, Jun Liu, \\ Xiao-Ning He and Hui Lin
}

College of Veterinary Medicine, Institute of Biotechnology, Northwest A\&F University, 1-06\#, Research Building, Yangling, Shaanxi 712100, People's Republic of China

Correspondence should be addressed to Y-M Zheng; Email: zhengyuemao@163.com

\begin{abstract}
We assessed the developmental ability of embryos cloned from porcine neural stem (NS) cells, amniotic fluid-derived stem (AFS) cells, fetal fibroblast cells, adult fibroblast, and mammary gland epithelial cells. The five cell lines were transfected with enhanced green fluorescence protein gene respectively using lipofection. NS and AFS cells were induced to differentiate in vitro. Stem cells and their differentiated cells were harvested for analysis of the markers using RT-PCR. The five cell lines were used for nuclear transfer. The two-cell stage-cloned embryos derived from each cell line were transferred into the oviducts of surrogate mothers. The results showed that both NS and AFS cells expressed POU5F1, THY1 and SOX2, and they were both induced to differentiate into astrocyte (GFAP ${ }^{+}$), oligodendrocyte $\left(\mathrm{GalC}^{+}\right)$, neuron $\left(\mathrm{NF}^{+}, \mathrm{ENO}^{+}\right.$, and $\left.\mathrm{MAP2}^{+}\right)$, adipocyte $\left(\mathrm{LPL}^{+}\right.$and PPARG-D $\left.{ }^{+}\right)$, osteoblast (osteonectin ${ }^{+}$and osteocalcin ${ }^{+}$), myocyte $\left(\mathrm{MYF6}^{+}\right.$and $\left.\mathrm{MYOD}^{+}\right)$, and endothelium (PECAM1 ${ }^{+}, \mathrm{CD}_{4}{ }^{+}, \mathrm{CDH}^{+}{ }^{+}$, and $\mathrm{NOS3}^{+}$) respectively. Seven cloned fetuses (28 days and 32 days) derived from stem cells were obtained. The in vitro developmental ability (morula-blastocyst rate was 28.26-30.07\%) and in vivo developmental ability (pregnancy rate were 1.67-2.17\%) of the embryos cloned from stem cells were higher $(\boldsymbol{P}<\mathbf{0 . 0 5 )}$ than that of the embryos cloned from somatic cells (morula-blastocyst rate was $16.27-19.28 \%$ and pregnancy rate was $\mathbf{0 . 0 0} \%$ ), which suggests that the undifferentiated state of the donor cells increases cloning efficiency.

Reproduction (2009) 137 793-801
\end{abstract}

\section{Introduction}

The development of nuclear transfer (NT) techniques have enabled researchers to generate cloned pigs (Betthauser et al. 2000, Polejaeva et al. 2000, Polejaeva 2001, Yin et al. 2002, Lee et al. 2003, Lagutina et al. 2006, Du et al. 2007). Although some believe that embryonic stem (ES) cells are not much better as the donor cell for NT (Oback \& Wells 2002), the success rate for producing cloned mice from several ES cell lines appears to be higher than the rates for other differentiated donor cells (Wakayama et al. 1999, Rideout et al. 2000). The results suggest that the undifferentiated state of the donor cells may increase the birth rate of cloned animals. Some researchers found that the developmental stage of donor embryos affects the cloning efficiency (Cheong et al. 1993, Hiiragi \& Solter 2005). In their results, cloned embryos receiving earlydevelopmental-stage embryo nuclei developed to term, but those receiving late-stage embryo nuclei had seriously limited development. Their results also suggest that using undifferentiated donor nuclei is effective for generating cloned animals. Yamazaki et al. (2001) also reported that cloned embryos develop to term with high efficiency (6\%) in freshly isolated fetal immature neural cells transferred into enucleated oocytes. Thus, the undifferentiated state of the donor cell, such as tissue-specific stem cells, may increase the animal cloning efficiency even if the cell is derived from a somatic cell lineage. Investigating other somatic stem cells used in NT is necessary.

Neural stem (NS) cells can be cultured over the long term and are able to self-renew in vitro (Reynolds \& Weiss 1992, 1996, Gage 2000, Philip et al. 2005). Amniotic fluid is known to contain stem cells (In't Anker et al. 2003, Prusa et al. 2004, Tsai et al. 2004). Human amniotic fluid-derived stem (AFS) cells can give rise to neurogenic, adipogenic, osteogenic, myogenic, and endothelial lineages, inclusive of all embryonic germ layers (De Coppi et al. 2007). The NS and AFS cells may increase cloning efficiency, if the undifferentiated state of the donor cells affects the success rate, as observed with ES cell donors.

Since first introduced as an expression marker by Chalfie et al. (1994), a fusion protein (green fluorescent protein, GFP) or a peptide tagged with GFP has been 
used as a marker to follow in vivo gene expression and real-time protein localization (Rizzuto et al. 1996, Wacker et al. 1997). In pigs, enhanced GFP (EGFP) gene was successfully used as an indicator without any adverse biological effects on in vitro development of transfected embryos (Park et al. 2001a, 2001b). The success in selecting and producing transgenic offspring using GFP as a marker has paved the way for GFP use in transgenic experimentation. With the aid of this virtually ideal transgenic marker, progress in developing efficient gene delivery systems will be greatly accelerated. However, there are no reports on production of cloned embryos using porcine NS and AFS cells transfected with EGFP. This study was conducted to assess the developmental ability of cloned embryos derived from NS and AFS cells, and compared the developmental ability with that of embryos cloned from other donor cells such as fetal fibroblast (FF) cells, adult fibroblast (AF) cells, and mammary gland epithelial (MGE) cells in the porcine.

\section{Results}

\section{Characterization of NS and AFS cells}

After two days of culture, NS cells proliferated as neurospheres (Fig. $1 \mathrm{~A}$ and $\mathrm{B}$ ). We have established AFS cell lines with a typical doubling time of about $48 \mathrm{~h}$ and
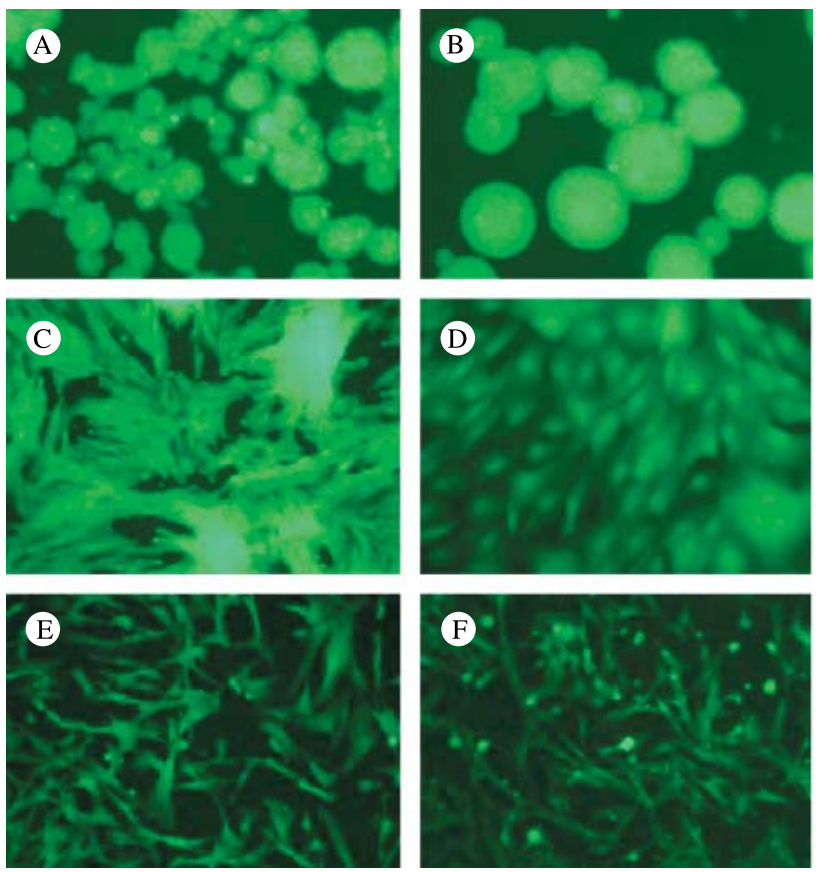

Figure 1 EGFP gene transgenic cells viewed under green fluorescence microscope, 10X. (A and B) NS cells ((A) cultured for two days and (B) cultured for three days), (C) AFS cells, (D) MGE cells, (E) FF cells, and $(F)$ AF cells. EGFP, enhanced green fluorescence protein; NS cells, neural stem cells; AFS cells, amniotic fluid-derived stem cells; MGE cells, mammary gland epithelial cells; FF cells, fetal fibroblast cells; AF cells, adult fibroblast cells.

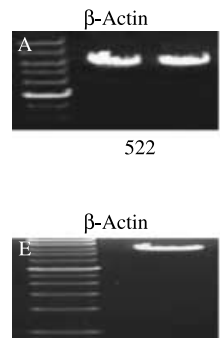

522

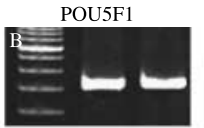

213

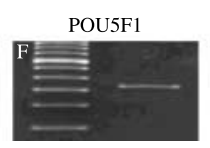

213

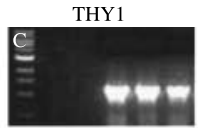

204

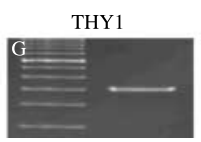

204

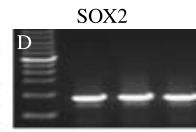

131

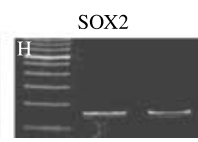

131
Figure 2 Markers of NS (B-D) and AFS (F-H) cells tested by RT-PCR. Positive control was $\beta$-actin. Products are shown with a 50-bp DNA ladder at the left of the gel and product sizes are under the margin. DNA marker is 50, 100, 150, 200, 250, 300, 350 (the brightest), 400, 450, 500,550 , and 600 bp. NS cells, neural stem cells; AFS cells, amniotic fluid-derived stem cells; RT-PCR.

without need for feeder layers. Sub-confluent cells show no evidence of spontaneous differentiation (Fig. 1C). The neurospheres and AFS cells were positive for the undifferentiated cell markers, POU5F1, THY1, and SOX2 (Fig. 2B-D and $\mathrm{F}-\mathrm{H}$ ).

\section{EGFP could be expressed in the cell lines}

EGFP could be expressed in NS, AFS, FF, AF, and MGE cells (Fig. 1). EGFP also could be expressed in the differentiated cells derived from NS and AFS cells (Fig. 3).

\section{Multilineage differentiation was characteristic of NS and AFS cells}

NS and AFS cells are broadly multipotent. Under specific inducing conditions, they are able to give rise to lineages representative of the three embryonic germ layers. We found that NS and AFS cells were able to differentiate along neurogenic, adipogenic, osteogenic, myogenic, and endothelial pathways (Fig. 3). Both NS and AFS cells were differentiated into astrocyte $\left(\mathrm{GFAP}^{+}\right)$, oligodendrocyte $\left(\mathrm{GalC}^{+}\right)$, neuron $\left(\mathrm{NF}^{+}, \mathrm{ENO}^{+}\right.$, and $\left.\mathrm{MAP}^{+}\right)$, adipocyte $\left(\mathrm{LPL}^{+}\right.$and PPARG-D $\left.{ }^{+}\right)$, osteoblast (osteonectin $^{+}$and osteocalcin ${ }^{+}$), myocyte $\left(\mathrm{MYF6}^{+}\right.$and $\mathrm{MYOD}^{+}$), and endothelium $\left(\mathrm{PECAM}^{+}, \mathrm{CD} 34^{+}\right.$, $\mathrm{CDH}_{5}{ }^{+}$and $\mathrm{NOS}_{3}^{+}$; Fig. 4).

\section{Developmental ability of embryos cloned from different donor cells}

The results showed that the in vitro developmental ability (morula-blastocyst rate was 28.26-30.07\%; Table 1) and in vivo developmental ability (pregnancy rate was $1.67-$ $2.17 \%$; Table 2) of the embryos cloned from stem cells were higher $(P<0.05)$ than that of the embryos cloned from somatic cells (morula-blastocyst rate was 16.27$19.28 \%$, and pregnancy rate was $0.00 \%$; Tables 1 and 2 ), 

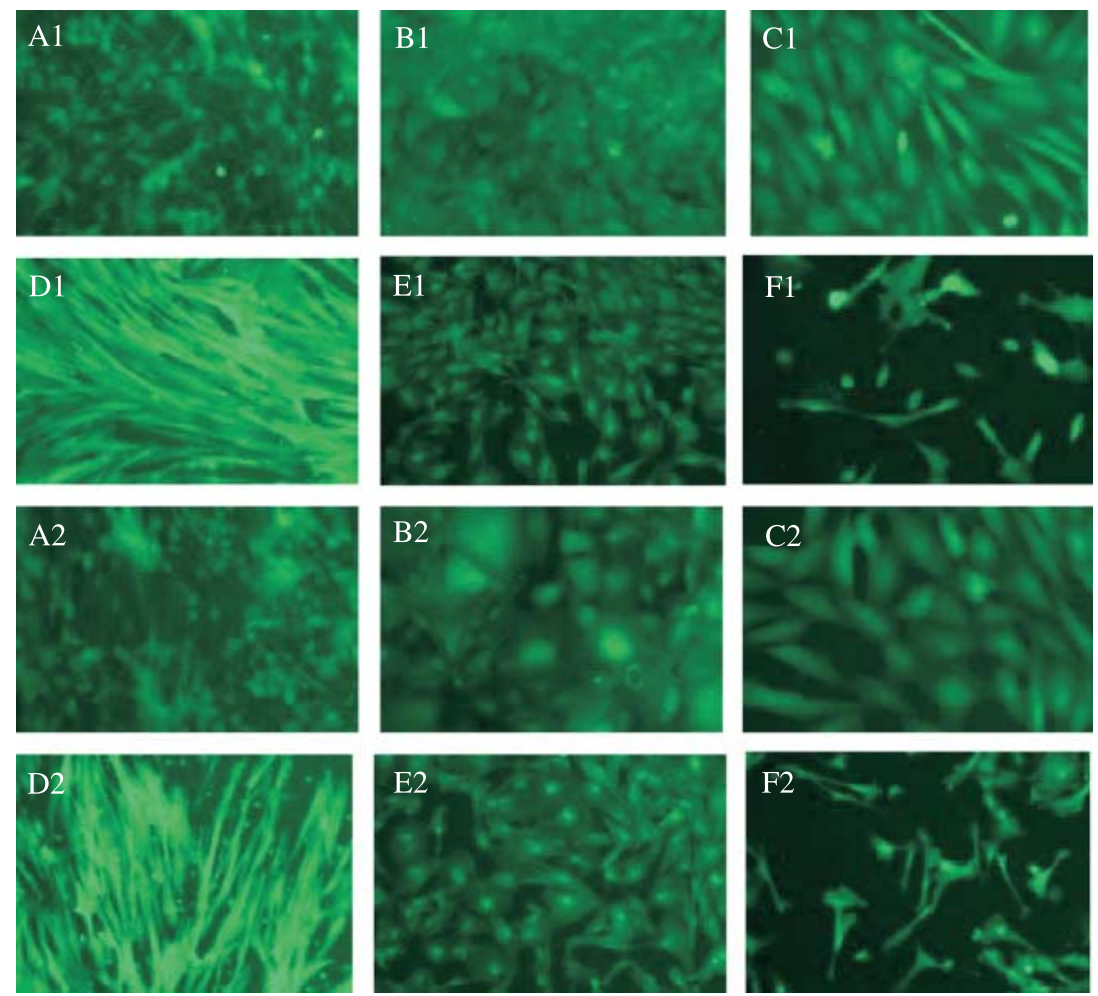

Figure 3 Differentiated cells derived from EGFP gene transfected NS (A1-F1) and AFS (A2-F2) cells viewed under green fluorescence microscope, $10 \times$. (A1 and A2) neurogenic cells, (B1 and B2) adipogenic cells, (C1 and $\mathrm{C} 2$ ) osteogenic cells, (D1 and D2) myogenic cells, (E1 and E2) endothelial cells, and (F1 and F2) control group cells. NS cells, neural stem cells; AFS cells, amniotic fluid-derived stem cells. which suggests that the undifferentiated state of the donor cells increases cloning efficiency. Seven cloned fetuses (28 days and 32 days) derived from stem cells were obtained. EGFP gene could be expressed in the cloned fetuses (Fig. $5 \mathrm{H}-\mathrm{J}$ ).

\section{Discussion}

Production of cloned pigs by somatic cell NT (SCNT) has unlimited value for developing critical biotechnology such as xenotransplantation (Prather et al. 1999, Polejaeva et al. 2000, Richard et al. 2002). Various efforts have been made to establish this technology (Wolf etal. 1998, Boquest et al. 2002, Im et al. 2004), and live piglets have been delivered after transfer of SCNT embryos (Betthauser et al. 2000, Onishi et al. 2000, Polejaeva et al. 2000). However, the viability of porcine SCNT embryos is poor, with an extremely low rate of cloned piglet production. Studies have demonstrated that many factors are involved in the development of porcine SCNT embryos (Polejaeva 2001). The factors include donor cell types, recipient oocytes, fusion/activation methods, and in vitro culture system. The success rate for cloning mice from ES cells is relatively high compared with that for differentiated somatic cells (Wakayama et al. 1999, Rideout et al. 2000). This suggests that a cell in an undifferentiated state may be suitable as a donor cell for animal cloning. Although ES cells may be effective in NT in mice, this process is limited in other species, where definitive ES cells have not been established. Investigation of other undifferentiated cell types, such as somatic stem cells, in NT is important for animal cloning techniques.

NS cells are a type of well-defined somatic stem cells that can proliferate and differentiate in vitro (Jingli et al. 2002, Philip et al. 2003, 2005). In this study, we isolated NS cells from porcine fetuses and the cells grown as spheres. The developmental potential differed between cloned embryos derived from neurospheres and from somatic cells, suggesting that the donor cells of the neurospheres we used were undifferentiated. We have demonstrated that stem cells can be obtained from porcine amniotic fluid. The AFS cells grow easily in culture. They are capable of extensive self-renewal, a defining property of stem cells. POU5F1 is expressed in totipotent ES and germ cells. A critical level of POU5F1 expression is required to sustain stem cell self-renewal and pluripotency. POU5F1 is not only a master regulator of pluripotency that controls lineage commitment, but is also the first and most recognized marker used for the identification of totipotent ES cells. THY1 can be used as a marker for a variety of stem cells (Chen et al. 1999). Ellis et al. (2004) show that SOX2 is expressed in multipotent NS cells at all stages of mouse ontogeny. In this study, porcine NS and AFS cells were positive for the undifferentiated cell markers, POU5F1, THY1, and SOX2 (Fig. 2B-D and $\mathrm{F}-\mathrm{H}$ ). These results also indicate that these cells were in an undifferentiated state. The surface marker profile of AFS cells and their expression 


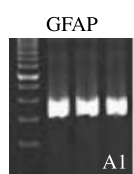

219

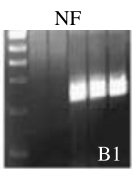

168

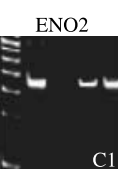

157

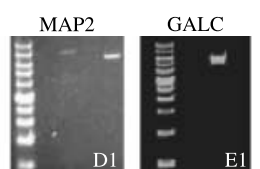

565

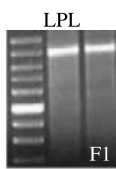

564

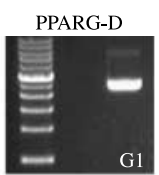

290

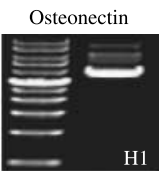

406

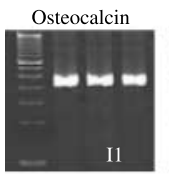

225

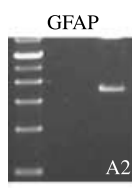

219

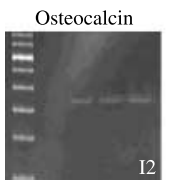

225

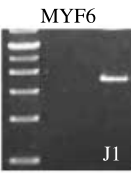

214

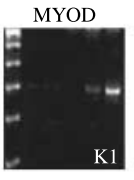

208

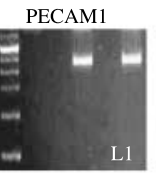

297

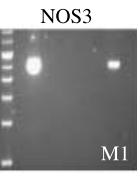

299

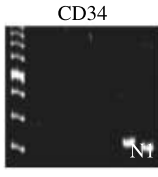

204

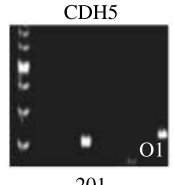

201

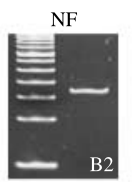

168

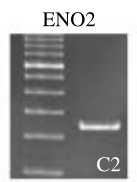

157

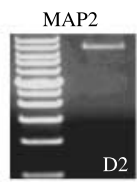

565

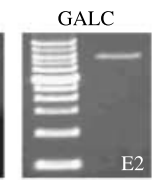

496

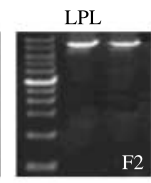

564

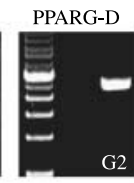

290

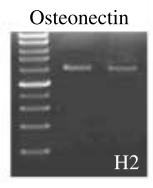

406

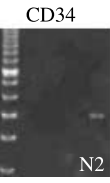

204

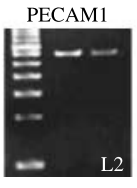

297

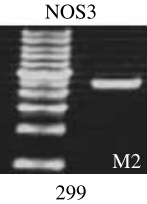

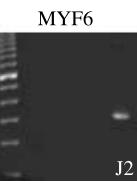

214

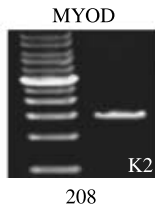

of the transcription factor POU5F1 suggest that they represent an intermediate stage between pluripotent ES cells (Evans \& Kaufman 1981, Martin 1981, James et al. 1998) and lineage-restricted adult stem cells.

AFS cells can serve as precursors to a broad spectrum of differentiated cell types. Siddiqui \& Atala (2004) found that AFS cells were able to differentiate along adipogenic, osteogenic, myogenic, endothelial, neurogenic, and hepatic pathways. We have assessed their multipotent character. This study shows that both NS and AFS cells are broadly multipotent, which were induced to differentiate into cell types representing each embryonic germ layer,

including cells of neuronal, adipogenic, osteogenic, myogenic, and endothelial lineages (Fig. 3). The induced differentiation to multiple fates could be documented by the expression of mRNAs for lineage-specific genes. Both NS and AFS cells could differentiate into astrocyte $\left(\mathrm{GFAP}^{+}\right)$, oligodendrocyte $\left(\mathrm{GalC}^{+}\right)$, neuron $\left(\mathrm{NF}^{+}\right.$, $\mathrm{ENO}_{2}{ }^{+}$, and $\mathrm{MAP}^{+}{ }^{+}$), adipocyte $\left(\mathrm{LPL}^{+}\right.$and PPARG$\left.\mathrm{D}^{+}\right)$, osteoblast (osteonectin ${ }^{+}$and osteocalcin ${ }^{+}$), myocyte $\left(\mathrm{MYF6}^{+}\right.$and $\mathrm{MYOD}^{+}$), and endothelium $\left(\mathrm{PECAM}^{+}{ }^{+}, \mathrm{CD}_{3} 4^{+}, \mathrm{CDH}^{+}{ }^{+}\right.$, and $\mathrm{NOS}_{3}{ }^{+}$; Fig. 4$)$.

A significant aspect of applying SCNT technology to generate transgenic embryos and/or offspring is the

Table 1 In vitro developmental ability of cloned embryos from different donor cells.

\begin{tabular}{|c|c|c|c|c|}
\hline Type of donor cell & $\begin{array}{l}\text { Reconstructed } \\
\text { efficiency }(\%)\end{array}$ & Two-cell rate (\%) & $\begin{array}{l}\text { Four- to eight-cell } \\
\text { rate }(\%)\end{array}$ & $\begin{array}{l}\text { Morula-blastocyst } \\
\text { rate }(\%)\end{array}$ \\
\hline \multicolumn{5}{|l|}{ Transgenic cells } \\
\hline NS cells & $82.97(268 / 323)^{a}$ & $64.18(172 / 268)^{a}$ & $45.90(123 / 268)^{\mathrm{a}}$ & $29.10(78 / 268)^{\mathrm{a}}$ \\
\hline AFS cells & $81.48(286 / 351)^{a}$ & $65.03(186 / 286)^{a}$ & $45.10(129 / 286)^{\mathrm{a}}$ & $30.07(86 / 286)^{a}$ \\
\hline FF cells & $81.62(191 / 234)^{a}$ & $53.40(102 / 191)^{\mathrm{b}}$ & $32.98(63 / 191)^{b}$ & $18.32(35 / 191)^{b}$ \\
\hline AF cells & $79.70(161 / 202)^{a}$ & $52.80(85 / 161)^{\mathrm{b}}$ & $32.30(52 / 161)^{\mathrm{b}}$ & $18.01(29 / 161)^{b}$ \\
\hline MGE cells & $78.67(166 / 211)^{a}$ & $51.20(85 / 166)^{b}$ & $28.92(48 / 166)^{\mathrm{b}}$ & $16.27(27 / 166)^{b}$ \\
\hline \multicolumn{5}{|l|}{ Non-transgenic cells } \\
\hline NS cells & $82.88(92 / 111)^{\mathrm{a}}$ & $65.22(60 / 92)^{\mathrm{a}}$ & $44.57(41 / 92)^{a}$ & $28.26(26 / 92)^{\mathrm{a}}$ \\
\hline AFS cells & $80.83(97 / 120)^{a}$ & $63.92(62 / 97)^{\mathrm{a}}$ & $44.33(43 / 97)^{\mathrm{a}}$ & $28.87(28 / 97)^{\mathrm{a}}$ \\
\hline FF cells & $81.37(83 / 102)^{\mathrm{a}}$ & $50.60(42 / 83)^{b}$ & $32.53(27 / 83)^{b}$ & $19.28(16 / 83)^{b}$ \\
\hline AF cells & $80.19(85 / 106)^{\mathrm{a}}$ & $54.12(46 / 85)^{\mathrm{b}}$ & $34.12(29 / 85)^{b}$ & $17.65(15 / 85)^{b}$ \\
\hline MGE cells & $79.00(79 / 100)^{\mathrm{a}}$ & $53.16(42 / 79)^{\mathrm{b}}$ & $29.11(23 / 79)^{b}$ & $17.72(14 / 79)^{\mathrm{b}}$ \\
\hline
\end{tabular}

Within the same column, values with same superscripts ( $a, b, c$ and $d)$ were not significantly different $(P>0.05)$, and values with different superscripts $(a, b, c$ and $d)$ were significantly different $(P<0.05)$. Reconstructed efficiency is the number of cloned embryos divided by the number of enucleated oocytes. NS cells, neural stem cells; AFS cells, amniotic fluid-derived stem cells; FF cells, fetal fibroblast cells; AF cells, adult fibroblast cells; MGE cells, mammary gland epithelial cells. 
Table 2 In vivo developmental ability of cloned embryos from different donor cells.

\begin{tabular}{lccc}
\hline $\begin{array}{l}\text { Type of } \\
\text { donor cell }\end{array}$ & $\begin{array}{l}\text { Number of two-cell } \\
\text { embryos transferred } \\
\text { into surrogate mothers }\end{array}$ & $\begin{array}{l}\text { Number of } \\
\text { fetuses }\end{array}$ & $\begin{array}{l}\text { Pregnancy } \\
\text { rate }(\%)\end{array}$ \\
\hline $\begin{array}{l}\text { Transgenic cells } \\
\text { NS cells }\end{array}$ & 92 & 2 & $2.17(2 / 92)$ \\
AFS cells & 96 & 2 & $2.08(2 / 96)$ \\
FF cells & 89 & 0 & $0.00(0 / 89)$ \\
AF cells & 86 & 0 & $0.00(0 / 86)$ \\
MGE cells & 93 & 0 & $0.00(0 / 93)$ \\
Non-transgenic cells & & & \\
NS cells & 95 & 2 & $2.11(2 / 95)$ \\
AFS cells & 60 & 1 & $1.67(1 / 60)$ \\
FF cells & 60 & 0 & $0.00(0 / 60)$ \\
AF cells & 60 & 0 & $0.00(0 / 60)$ \\
MGE cells & 60 & 0 & $0.00(0 / 60)$ \\
\hline
\end{tabular}

NS cells, neural stem cells; AFS cells, amniotic fluid-derived stem cells; FF cells, fetal fibroblast cells; AF cells, adult fibroblast cells; MGE cells, mammary gland epithelial cells.

origin/type of nuclear donor cells and the in vitro techniques utilized to obtain viable donor nuclei for cloning procedures. Genetically transformed cells can be selected in vitro, and only the cells with stable, integrated transgenes are used as a source of nuclear donor cells to reconstruct the enucleated oocytes through somatic cell cloning. For the establishment of transgenic cell lines, various selection markers with different actions and advantages have been employed, including either antibiotics such as neomycin/geneticin G418 (Uhm et al. 2000, Park et al. 2001a, 2001b, Bordignon et al. 2003), puromycin (Watanabe et al. 2005) and blasticidin S (Michalak et al. 2004), or EGFP (Arat et al. 2001, 2002, Zhang et al. 2006). Since it was first introduced by Chalfie et al. (1994), the EGFP-mediated genetic reporter system, which was derived from the biochemiluminescent jellyfish Aequorea victoria, is now emerging and provides us with a valuable xenogeneic selection marker because of its expression in a broad range of organisms and its lack of reported obvious adverse biological (i.e. cytotoxic) effects (Murakami et al. 1999, Funahashi et al. 2001, Devgan et al. 2004, Zhang et al. 2006). So far, the 238 amino acid residue EGFP protein has been applied for various purposes as a useful marker among others for the vital monitoring of the efficiency of somatic cell transfection and selection of in vitro cultured transgenic cells (Ono et al. 2001, Hyun et al. 2003, Gong et al. 2004). Porcine EGFP transgene-expressing blastocysts and/or offspring have been created from cultured somatic cells (Park et al. 2001a, 2001b, Lai et al. 2002, Roh \& Hwang 2002, Lee et al. 2003, 2005, Zhang et al. 2006). Although cloned embryos from NS cells had been produced (Eiji et al. 2006), there are no reports focused on applying EGFP-transgenic stem cells to porcine SCNT technology. This is the first report on production of cloned embryos using porcine NS and AFS cells transfected with EGFP. Our results demonstrated that the embryos could be produced using NS and AFS cells transfected with EGFP, and EGFP could be expressed in the cloned embryos and fetuses. Our results showed that there were significant differences $(P<0.05)$ in developmental potential between the cloned embryos derived from stem cells (NS and AFS cells) and somatic cells (FF, AF, and MGE cells), which acted as donor cells. The developmental potential of the cloned embryos derived from stem cells (NS and AFS cells) were higher than that of the cloned embryos derived from somatic cells (Tables 1 and 2).

We conclude that porcine NS and AFS cells are broadly multipotent, which could be induced to differentiate into cell types representing each embryonic
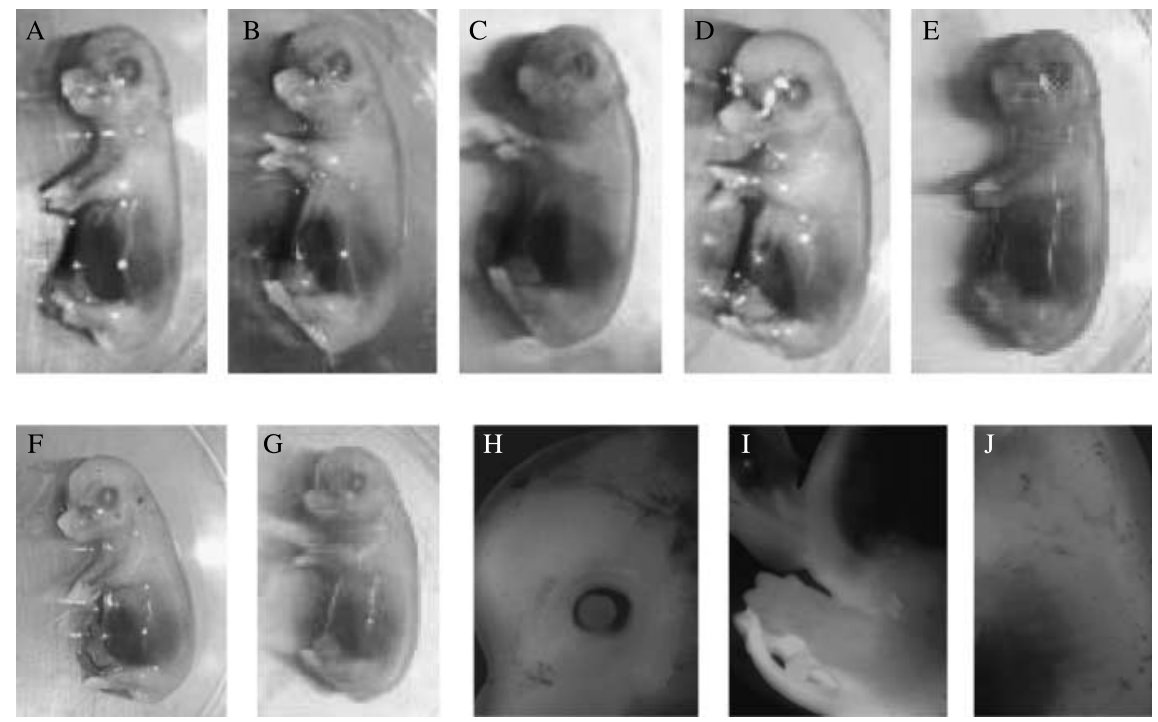

Figure 5 Cloned fetuses derived from NS and AFS cells. (A-D, H and I) Fetuses (28 days) from NS cells, (E-G and J) fetuses (32 d) from AFS cells, and $(\mathrm{H}-\mathrm{J})$ photos viewed under green fluorescence microscope. NS cells, neural stem cells; AFS cells, amniotic fluid-derived stem cells. 
germ layer, including cells of neuronal, adipogenic, osteogenic, myogenic, and endothelial lineages. The developmental potential of the cloned embryos derived from stem cells (NS and AFS cells) were higher $(P<0.05)$ than that of the cloned embryos derived from somatic cells (FF, AF, and MGE cells), which suggests that the undifferentiated state of the donor cell increases cloning efficiency. EGFP could be expressed in the cloned fetuses, which will contribute to obtaining EGFPtransgenic porcines in later research.

\section{Materials and Methods}

Unless otherwise mentioned, all chemicals used in this study were purchased from Sigma Chemical Co.

\section{Animals \\ Porcine fetuses were obtained off-site from a pregnant sow placed under general anesthesia and terminated prior to waking, according to a protocol approved by the Institutional Animal Care and Use Committee. All tissues were acquired in compliance with National Institutes of Health and institutional guidelines.}

\section{Isolation of NS, AFS, FF, AF, and MGE cells}

The isolation of porcine NS cells followed the following protocol. An embryonic day 30 (E30) fetal pig was obtained offsite from a pregnant sow placed under general anesthesia and terminated prior to waking. The craniums were removed, and the subventricular zone of the brain was dissected and minced with fine scissors. The brain tissue were cut up into smaller pieces, and treated with enzyme solution, light inhibitory solution, and heavy inhibitory solution respectively in a tube at $37^{\circ} \mathrm{C}$. Then the heavy inhibitory solution was removed and $5 \mathrm{ml}$ of NSCs basal medium was added. After the tissue chunks were broken up, the appropriate amount of cells $\left(1 \times 10^{6}\right.$ cells $/ 6-\mathrm{cm}$ plate or $2 \times 10^{6}$ cells/ $10-\mathrm{cm}$ plate) was added into a non-coated bacterial plate containing NSCs complete medium. The cells were incubated in $37{ }^{\circ} \mathrm{C}, 5 \% \mathrm{CO}_{2}$ incubator for several days. Once the spheres had formed, the medium was replaced every three days. NSCs were passaged when the neurospheres were sufficiently large. RNA was then extracted from the neurospheres for RT-PCR analysis of the NSCs markers. NSCs complete medium was composed of $10 \mathrm{ml} \mathrm{NSCs}$ basal medium, $10 \mu \mathrm{l} \mathrm{EGF}(100 \mathrm{ng} / \mu \mathrm{l})$, and $10 \mu \mathrm{l}$ bFGF (10 ng/ $\mu \mathrm{l}$; Gibco). NSCs basal medium was composed of $48.5 \mathrm{ml}$ of NSCs medium, $1 \mathrm{ml} \mathrm{B27}$ supplement, and $0.5 \mathrm{ml}$ N2 supplement (Gibco). NSCs medium was composed of $500 \mathrm{ml}$ neurobasal medium (Gibco), $5 \mathrm{ml} 100 \times$ penicillinstreptomycin, and $5 \mathrm{ml} 100 \times$ L-glutamine. Enzyme solution was composed of $20 \mathrm{ml}$ dissociation medium, $6.4 \mathrm{mg}$ cysteine, and $200 \mu \mathrm{l}$ papain (Roche). Heavy inhibitory solution was composed of $6 \mathrm{ml}$ dissociation medium, $60 \mathrm{mg}$ BSA, and $60 \mathrm{mg}$ trypsin inhibitor. Light inhibitory solution was composed of $9 \mathrm{ml}$ dissociation medium and $1 \mathrm{ml}$ heavy inhibitory solution. Dissociation medium was composed of $98 \mathrm{mmol} / \mathrm{l}$
$\mathrm{Na}_{2} \mathrm{SO}_{4}, 30 \mathrm{mmol} / \mathrm{l} \mathrm{K}_{2} \mathrm{SO}_{4}, 5.8 \mathrm{mmol} / \mathrm{l} \mathrm{MgCl}{ }_{2}, 0.25 \mathrm{mmol} / \mathrm{l}$ $\mathrm{CaCl}_{2}, 1 \mathrm{mmol} / \mathrm{l}$ HEPES, $20 \mathrm{mmol} / \mathrm{l}$ glucose, $0.001 \%$ phenol red, and $0.125 \mathrm{mmol} / \mathrm{l} \mathrm{NaOH}$.

The isolation of porcine AFS cells followed the following protocol. Amniotic fluid was collected from E30 fetal porcine, and the recovered cells were cultured in 24-well dishes. After expansion to confluence, a single-cell suspension was prepared by gentle trypsinization, and cells were harvested by trypsinization. AFS cells were grown in $\alpha$-MEM medium (Gibco, Invitrogen) containing 15\% ES-FBS, 1\% glutamine, and $1 \%$ penicillin/streptomycin (Gibco), supplemented with 18\% Chang B and $\%$ Chang C (Irvine Scientific, Santa Ana, CA, USA) at $37{ }^{\circ} \mathrm{C}$ with $5 \% \mathrm{CO}_{2}$ atmosphere. AFS cells were subcultured routinely at a dilution of $1: 4$ to $1: 8$ and not permitted to expand beyond $70 \%$ of confluence. Clonal AFS cell lines were generated by the limiting dilution method in 96-well plates. Medium was replaced every three days. AFS cells were passaged, and RNA was then extracted for RT-PCR analysis of the AFS cells markers.

The techniques used for isolation of porcine FF cells, AF, and MGE cells used in this study were similar as described previously (Zheng et al. 2006).

\section{Transfection of EGFP gene into NS, AFS, FF, AF, and MGE cells}

The day before transfection, NS, AFS, FF, AF, and MGE cells (at passage 3-6) were trypsinized, counted, and plated into 35-mm culture dishes to reach $80 \%$ confluency on the day of transfection. Totally $40 \mu \mathrm{l}$ (Invitrogen) of Lipofectamine 2000 and pEGFP-N1 of $3 \mu \mathrm{g}$ (Clontech) were dissolved into $200 \mu \mathrm{l}$ serum-antibiotics-free culture medium (SFCM) respectively in two tubes. The solution of the two tubes were mixed together, and then one $600 \mu \mathrm{l} \mathrm{SFCM}$ was added. Then, $2 \mathrm{ml}$ Lipofectamine 2000-pEGFP-N1 mixture was ready to be used. Cells were rinsed with SFCM and cultured in $1 \mathrm{ml}$ Lipofectamine 2000-pEGFP-N1 mixture for $20 \mathrm{~h}$. Then, the mixture was removed and the cells were cultured with culture medium containing G418 $(350 \mu \mathrm{g} / \mathrm{ml})$. Expression of EGFP in the cells was monitored under an inverted u.v. microscope (TE2000-U, Nikon Inc., Tokyo, Japan).

\section{Differentiation of NS and AFS cells in culture}

The protocols used for differentiation of porcine NS and AFS cells used in this study were similar to those described by De Coppi et al. (2007). RNA was then extracted for RT-PCR analysis to confirm lineage-specific gene expression.

\section{RNA extraction and RT-PCR}

Analysis of mRNA expression by RT-PCR was carried out using standard protocols. Briefly, total RNA was extracted from stem and differentiated cells, using Purescript RNA Isolation Kit (Gentra Systems, Inc., Minneapolis, MN, USA) according to the manufacturer's protocol. Any residual genomic DNA was eliminated by treatment with DNase (DNA-free; Ambion, Inc., Austin, TX, USA). PCR was carried out in a final volume of $50 \mu \mathrm{l}$ with $3 \mu \mathrm{l}$ of cDNA template, $0.75 \mu \mathrm{l}$ of forward and 
reverse primers $(0.5 \mu \mathrm{g} / \mu \mathrm{l}$; Qiagen), and 1.25 units of Taq DNA Polymerase (Amersham) on a Genius thermocycler (Techne, Minneapolis, MN, USA). Initial denaturation for $5 \mathrm{~min}$ at $95^{\circ} \mathrm{C}$ was followed by 40 cycles of $30 \mathrm{~s}$ at $94{ }^{\circ} \mathrm{C}, 15 \mathrm{~s}$ at the corresponding annealing temperature, and $45 \mathrm{~s}$ at $72{ }^{\circ} \mathrm{C}$. The final step consisted of $5 \mathrm{~min}$ of extension at $72^{\circ} \mathrm{C}$. PCR products were run on $2 \%$ agarose gels and visualized with ethidium bromide against a 50-bp DNA ladder.

\section{In vitro maturation of pig oocytes}

Ovaries were retrieved from prepubertal gilts at a local slaughterhouse and transported to the laboratory in physiological saline at $30-35{ }^{\circ} \mathrm{C}$ within $2 \mathrm{~h}$. Oocytes were aspirated from antral follicles (3-7 mm in diameter) and cultured in a $100 \mu \mathrm{l}$ droplet of maturation medium (BSA-free NCSU23 with $10 \%$ porcine follicular fluid, $0.1 \mathrm{mg} / \mathrm{ml}$ cysteine, $1 \%$ MEM non-essential amino acid, and $0.2 \mathrm{mM}$ pyruvate) with hormonal supplementation $(2 \mathrm{~g} / \mathrm{ml}$ Follitropin- $\mathrm{V}$, Vetrepharm, Ontario, Canada) in NCSU23 medium at $38.5{ }^{\circ} \mathrm{C}$ under $5 \% \mathrm{CO}_{2}$ in air for $44 \mathrm{~h}$.

\section{Preparation of donor cells}

NS, AFS, FF, AF, and MGE cells were used for NT respectively. Immediately before whole-cell injection, donor cells were trypsinized, washed by centrifugation, and resuspended in injection medium of TL-HEPES and $10 \%$ polyvinylpyrrolidone solution at $1: 1$.

\section{Enucleation and whole-cell injection}

Recipient oocytes were prepared by centrifugation for $10 \mathrm{~min}$ in an Eppendorf centrifuge at $12000 \boldsymbol{g}$ in $200 \mu \mathrm{l}$ TL-HEPES medium to allow detection of the first polar body. Only oocytes with excellent morphology and a visible polar body were selected for this experiment. For enucleation, groups of oocytes were transferred into droplets of TL-HEPES containing $5 \mu \mathrm{g} / \mathrm{ml}$ cytochalasin $\mathrm{B}(\mathrm{CB})$, which had previously been placed in the operation chamber on the microscope stage. In the initial experiments, enucleation was accomplished by aspiration of the first polar body and the metaphase II plate in a small amount ( $<15 \%$ of the oocyte volume) of cytoplasm. Successful enucleation was confirmed by examination after staining with $5 \mu \mathrm{g} / \mathrm{ml}$ Hoechst 33342. Successful enucleation was confirmed by staining the isolated cytoplasm. Whole-cell injection was conducted according to the following protocol. Briefly, donor cells were transferred to TL-HEPES containing 10\% (w/v) polyvinylpyrrolidone and kept at room temperature. A microdrop $(10 \mu \mathrm{l})$ of injection medium under light mineral oil was placed in the lid of a 60-mm sterile culture dish, which was positioned on an inverted microscope (Olympus) equipped with micromanipulators (Nikon). Individual donor cells were aspirated into the injection pipette with a sharp, beveled tip (inner diameter 10-12, 15-18, and 20-25 $\mu \mathrm{m}$ ), and injected into an enucleated oocyte via the slit that was already made during the enucleation process. The cell expelled into the cytoplasm of the oocyte.

\section{Activation of oocytes}

Reconstructed embryos were washed and pre-incubated for $20 \mathrm{~s}$ in activation medium $(0.25 \mathrm{M}$ mannitol solution supplemented with $0.01 \%$ polyvinyl alcohol, $0.5 \mathrm{mM}$ HEPES, $0.1 \mathrm{mM}$ $\mathrm{CaCl}_{2}-\mathrm{H}_{2} \mathrm{O}$, and $0.1 \mathrm{mM} \mathrm{MgCl} 2-6 \mathrm{H}_{2} \mathrm{O}$ with $\mathrm{pH}$ 7.2) at room temperature. Electrical stimulation was delivered with a BTX Electro Cell Manipulator (Biotechnologies and Experimental Research, Inc., SanDiego, CA, USA) to a chamber with two parallel platinum wire electrodes $(200 \mu \mathrm{m}$ outer diameter), spaced $1 \mathrm{~mm}$ apart overlaid with activation medium. The reconstructed oocytes were exposed to an electrical pulse for $10 \mathrm{~s}$ at $5 \mathrm{~V} \mathrm{AC}$ followed by a $1 \times 30 \mu$ s pulse at $2.2 \mathrm{kV} / \mathrm{cm} \mathrm{DC}$ at room temperature. Non-manipulated, but u.v.-exposed, oocytes were activated $3 \mathrm{~h}$ after u.v. exposure as a control. Following somatic cell injections, oocytes were either immediately activated or then cultured in NCSU23 medium containing $10 \mu \mathrm{g} / \mathrm{ml} \mathrm{CB}$ and cycloheximide for $5 \mathrm{~h}$ or left in NCSU23 medium at $38.5{ }^{\circ} \mathrm{C}$ under $5 \% \mathrm{CO}_{2}$ in air for $1.5,3$, and $6 \mathrm{~h}$ before electrical activation treatment.

\section{In vitro culture of cloned embryos}

After activation treatments, surviving cloned embryos were thoroughly washed and cultured in 50- $\mu$ l drops of NCSU23 supplemented with $1 \%$ MEM non-essential amino acid and $0.4 \mathrm{mg} / \mathrm{ml} \mathrm{BSA}$ for seven days at $38.5{ }^{\circ} \mathrm{C}$ in $5 \% \mathrm{CO}_{2}$ in air without a medium change. After $72-96 \mathrm{~h}$ of in vitro culture, cleavage-stage embryos were selected. Then 20-40 of cleaved embryos were cultured together in a $50-\mu$ l drop of NCSU23 medium supplemented with $10 \%$ FBS at $38.5^{\circ} \mathrm{C}$ in an incubator with $100 \%$ humidity and $5 \% \mathrm{CO}_{2}$ in air for additional $72 \mathrm{~h}$. At the end of the in vitro culture period (days 6-7), embryos were evaluated morphologically for blastocyst formation. Two-cell rate, four- to eight-cell rate and morulablastocyst rate were evaluated under a stereomicroscope.

\section{Surgical embryo transfer and pregnancy diagnosis}

The two-cell stage-cloned embryos derived from each cell line (NS, AFS, FF, AF, and MGE cells) were transferred into the oviducts of the naturally cycling gilts on the first day of standing estrus. Examination of the ovaries during embryo transfer confirmed that none of the surrogates had completed ovulation. Non-return surrogates were checked for pregnancy by transabdominal ultrasound examination at day 25 after embryo transfer and at 2 weeks.

\section{Statistical analysis}

All data were pooled and then tested by $\chi^{2}$-analysis for significant differences. Differences between the experimental groups were considered to be significant at a level of $P<0.05$.

\section{Declaration of interest}

We declare that there is no conflict of interest that could be perceived as prejudicing the impartiality of the research reported, and there is no any financial or other potential conflict of interest. 


\section{Funding}

This work was supported by a grant from Northwest A\&F University Research Foundation (07ZR001).

\section{Acknowledgements}

We thank everyone for assistance with this project.

\section{References}

Arat S, Rzucidlo SJ, Gibbons J, Miyoshi K \& Stice SL 2001 Production of transgenic bovine embryos by transfer of transfected granulosa cells into enucleated oocytes. Molecular Reproduction and Development 60 20-26.

Arat S, Gibbons J, Rzucidlo SJ, Respess DS, Tumlin M \& Stice SL 2002 In vitro development of bovine nuclear transfer embryos from transgenic clonal lines of adult and fetal fibroblast cells of the same genotype. Biology of Reproduction 66 1768-1774.

Betthauser J, Forsberg E, Augenstein M, Childs L, Eilertsen K, Enos J, Forsythe T, Golueke P, Jurgella G, Koppang R et al. 2000 Production of cloned pigs from in vitro systems. Nature Biotechnology 18 1055-1058.

Boquest AC, Grupen CG, Harrison SJ, Mcllfatrick SM, Ashman RJ, D'Apice AJF \& Nottle MB 2002 Production of cloned pigs from cultured fetal fibroblast cells. Biology of Reproduction 66 1283-1287.

Bordignon V, Keyston R, Lazaris A, Bilodeau AS, Pontes JH, Arnold D, Fecteau G, Keefer C \& Smith LC 2003 Transgene expression of green fluorescent protein and germ line transmission in reconstructed calves derived from in vitro-transfected somatic cells. Biology of Reproduction 68 2013-2023.

Chalfie M, Tu Y, Euskirchen G, Ward WW \& Prasher DC 1994 Green fluorescent protein as a marker for gene expression. Science $\mathbf{2 6 3}$ 802-805.

Chen XD, Qian HY, Neff L, Satomura K \& Horowitz MC 1999 Thy-1 antigen expression by cells in the osteoblast lineage. Journal of Bone and Mineral Research 14 362-375.

Cheong HT, Takahashi Y \& Kanagawa H 1993 Birth of mice after transplantation of early cell-cycle-stage embryonic nuclei into enucleated oocytes. Biology of Reproduction 48 958-963.

De Coppi P, Bartsch G Jr, Siddiqui MM, Xu T, Santos CC, Perin L, Mostoslavsky G, Serre AC, Snyder EY, Yoo JJ et al. 2007 Isolation of amniotic stem cell lines with potential for therapy. Nature Biotechnology 25 100-106.

Devgan V, Rao MR \& Seshagiri PB 2004 Impact of embryonic expression of enhanced green fluorescent protein on early mouse development. Biochemical and Biophysical Research Communications 313 1030-1036.

Du Y, Kragh PM, Zhang Y, Li J, Schmidt M, Bøgh IB, Zhang X, Purup S, Jørgensen AL, Pedersen AM et al. 2007 Piglets born from handmade cloning, an innovative cloning method without micromanipulation. Theriogenology 68 1104-1110.

Eiji M, Hiroshi O, Satoshi K, Nguyen VT, Takafusa H, Sayaka W, Mitsuko K, Eimei S \& Teruhiko W 2006 Developmental ability of cloned embryos from neural stem cells. Reproduction 132 849-857.

Ellis P, Fagan BM, Magness ST, Hutton S, Taranova O, Hayashi S, McMahon A, Rao M \& Pevny L 2004 SOX2, a persistent marker for multipotential neural stem cells derived from embryonic stem cells, the embryo or the adult. Developmental Neuroscience 26 148-165.

Evans MJ \& Kaufman MH 1981 Establishment in culture of pluripotential cells from mouse embryos. Nature 292 154-156.

Funahashi H, Ideta A, Konishi M, Urakawa M, Uruno K, Aoyagi Y, Okabe M \& Niwa K 2001 Nuclear transfer of blastomeres expressing EGFP-reporter gene may improve the efficiency of transgenic cattle. Cloning Stem Cells 3 183-190.

Gage FH 2000 Mammalian neural stem cells. Science 287 1433-1438.

Gong G, Dai Y, Fan B, Zhu H, Zhu S, Wang H, Wang L, Tang B, Li R, Wan R et al. 2004 Birth of calves expressing the enhanced green fluorescent protein after transfer of fresh or vitrified/thawed blastocysts produced by somatic cell nuclear transfer. Molecular Reproduction and Development $69278-288$.

Hiiragi T \& Solter D 2005 Reprogramming is essential in nuclear transfer. Molecular Reproduction and Development 70 417-421.

Hyun S, Lee G, Kim D, Kim H, Lee S, Nam D, Jeong Y, Kim S, Yeom S, Kang S et al. 2003 Production of nuclear transfer-derived piglets using porcine fetal fibroblasts transfected with the enhanced green fluorescent protein. Biology of Reproduction 69 1060-1068.

Im GS, Lai L, Liu Z, Hao Y, Wax D, Bonk A \& Prather RS 2004 In vitro development of preimplantation porcine nuclear transfer embryos cultured in different media and gas atmospheres. Theriogenology 61 $1125-1135$.

In't Anker PS, Scherjon SA, Kleijburg-Van Der KC, Noort WA, Claas Frans HJ, Willemze R, Fibbe WE \& Kanhal Humphrey HH 2003 Amniotic fluid as a novel source of mesenchymal stem cells for therapeutic transplantation. Blood 102 1548-1549.

James AT, Joseph IE, Sander SS, Michelle AW, Jennifer JS, Vivienne SM \& Jeffrey MJ 1998 Embryonic stem cell lines derived from human blastocysts. Science 282 1145-1147.

Jingli C, Yuanyuan W, Takumi M, Jeanne LP, Mary TL, Kurt HA, Gerald JS \& Mahendra SR 2002 Properties of a fetal multipotent neural stem cell (NEP cell). Developmental Biology 251 221-240.

Lagutina I, Lazzari G \& Galli C 2006 Birth of cloned pigs from zona-free nuclear transfer embryos developed in vitro to blastocyst before transfer. Cloning and Stem Cells 8 283-293.

Lai L, Park KW, Cheong HT, Kühholzer B, Samuel M, Bonk A, Im GS, Rieke A, Day BN, Murphy CN et al. 2002 Transgenic pig expressing the enhanced green fluorescent protein produced by nuclear transfer using colchicine-treated fibroblasts as donor cells. Molecular Reproduction and Development 62 300-306.

Lee JW, Wu SC, Tian XC, Barber M, Hoagland T, Riesen J, Lee KH, Tu CF, Cheng WTK \& Yang XZ 2003 Production of cloned pigs by whole-cell intracytoplasmic microinjection. Biology of Reproduction 69 995-1001.

Lee GS, Kim HS, Hyun SH, Lee SH, Jeon HY, Nam DH, Jeong YW, Kim S, Kim JH, Han JY et al. 2005 Production of transgenic cloned piglets from genetically transformed fetal fibroblasts selected by green fluorescent protein. Theriogenology 63 973-991.

Martin GR 1981 Isolation of a pluripotent cell line from early mouse embryos cultured in medium conditioned by teratocarcinoma stem cells. PNAS 78 7634-7638.

Michalak E, Katska-Ksiazkiewicz L, Kalak R, Lipinski D, Wielgus K, Jarmuz M, Szalata M, Rynska B, Smorag Z \& Slomski R 2004 In vitro transfection of fibroblasts and evaluation of transgenesis in long-term cell cultures. Annals of Animal Science 4 233-240.

Murakami M, Fahrudin M, Varisanga MD \& Suzuki T 1999 Fluorescence expression by bovine embryos after pronuclear microinjection with the EGFP gene. Journal of Veterinary Medical Science 61 843-847.

Oback B \& Wells D 2002 Donor cells for nuclear cloning: many are called, but few are chosen. Cloning Stem Cells 4 147-168.

Onishi A, Iwamoto M, Akita T, Mikawa S, Takeda K, Awata T, Hanada H \& Perry AC 2000 Pig cloning by microinjection of fetal fibroblast nuclei. Science 289 1188-1190.

Ono Y, Shimozawa N, Ito M \& Kono T 2001 Cloned mice from fetal fibroblast cells arrested at metaphase by a serial nuclear transfer. Biology of Reproduction 64 44-50.

Park KW, Cheong HT, Lai L, Im GS, Kuhholzer B, Bonk A, Samuel M, Rieke A, Day BN, Murphy CN et al. 2001 a Production of nuclear transfer-derived swine that express the enhanced green fluorescent protein. Animal Biotechnology 12 173-181.

Park KW, Kühholzer B, Lai L, Machaty Z, Sun QY, Day BN \& Prather RS $2001 b$ Development and expression of the green fluorescent protein in porcine embryos derived from nuclear transfer of transgenic granulosaderived cells. Animal Reproduction Science 68 111-120.

Philip HS, Peter JB, Tannin JF, Hailing S, Diane KO \& Henry K 2003 Isolation and characterization of neural progenitor cells from postmortem human cortex. Journal of Neuroscience Research 74 838-851.

Philip HS, Hubert N, Ivan IK, Boback Z, Michael JY \& Henry K 2005 Expression of neurodevelopmental markers by cultured porcine neural precursor cells. Stem Cells 23 1286-1294.

Polejaeva IA 2001 Cloning pigs: advances and applications. Reproduction 58 293-300. 
Polejaeva IA, Chen SH, Vaught TD, Page RL, Mullins J, Ball S, Dai Y, Boone J, Walker S, Ayares DL et al. 2000 Cloned pigs produced by nuclear transfer from adult somatic cells. Nature 407 86-90.

Prather RS, Tao T \& Machaty Z 1999 Development of the techniques for nuclear transfer in pigs. Theriogenology 51 487-498.

Prusa A, Marton E, Rosner M, Bettelheim D, Lubec G, Pollack A, Bernaschek G \& Hengstschläger M 2004 Neurogenic cells in human amniotic fluid. American Journal of Obstetrics and Gynecology 191 309-314.

Reynolds BA \& Weiss S 1992 Generation of neurons and astrocytes from isolated cells of the adult mammalian central nervous system. Science 255 1707-1710.

Reynolds BA \& Weiss S 1996 Clonal and population analyses demonstrate that an EGF-responsive mammalian embryonic CNS precursor is a stem cell. Developmental Biology 175 1-13.

Richard JEA, Carrie BH, Pam T, Emma LR, Andrew R, Stephen BD, Anne ER \& Roger AB 2002 The potential for circuit reconstruction by expanded neural precursor cells explored through porcine xenografts in a rat model of Parkinson's disease. Experimental Neurology 175 98-111.

Rideout WM, Wakayama T, Wutz A, Eggan K, Jackson-Grusby L, Dausman J, Yanagimachi R \& Jaenisch R 2000 Generation of mice from wild-type and targeted ES cells by nuclear cloning. Nature Genetics 24 109-110.

Rizzuto R, Brini M, De Giorgi F, Rossi R, Heim R, Tsien RY \& Pozzan T 1996 Double labelling of subcellular structures with organelle-targeted GFP mutants in vivo. Current Biology 6 183-188.

Roh S \& Hwang WS 2002 In vitro development of porcine parthenogenetic and cloned embryos: comparison of oocyte-activating techniques, various culture systems and nuclear transfer methods. Reproduction, Fertility, and Development 14 93-99.

Siddiqui MM \& Atala A 2004 Amniotic fluid-derived pluripotential cells: adult and fetal. Handbook of Stem Cells 2 175-180.

Tsai MS, Lee JL, Chang YJ \& Hwang SM 2004 Isolation of human multipotent mesenchymal stem cells from second-trimester amniotic fluid using a novel two-stage culture protocol. Human Reproduction 19 1450-1456.

Uhm SJ, Kim NH, Kim T, Chung HM, Chung KH, Lee HT \& Chung KS 2000 Expression of enhanced green fluorescent protein and neomycin resistant
(NeoR) genes in porcine embryos following nuclear transfer with porcine fetal fibroblasts transfected by retrovirus vector. Molecular Reproduction and Development 53 331-337.

Wacker I, Kaether C, Kromer A, Migala A, Almers W \& Gerdes HH 1997 Microtubule-dependent transport of secondsretory vesicles visualized in real time with a GFP-tagged secondsretory protein. Journal of Cell Science 110 1453-1463.

Wakayama T, Rodriguez I, Perry AC, Yanagimachi R \& Mombaerts P 1999 Mice cloned from embryonic stem cells. PNAS 96 14984-14989.

Watanabe S, Iwamoto M, Suzuki S, Fuchimoto D, Honma D, Nagai T, Hashimoto M, Yazaki S, Sato M \& Onishi A 2005 A novel method for the production of transgenic reconstructed pigs: electroporation-mediated gene transfer to non-cultured cells and subsequent selection with puromycin. Biology of Reproduction 72 309-315.

Wolf E, Zakhartchenko V \& Brem G 1998 Nuclear transfer in mammals: recent developments and future perspectives. Journal of Biotechnology 65 99-110.

Yamazaki Y, Makino H, Hamaguchi-Hamada K, Hamada S, Sugino H, Kawase E, Miyata T, Ogawa M, Yanagimachi R \& Yagi T 2001 Assessment of the developmental totipotency of neural cells in the cerebral cortex of mouse embryo by nuclear transfer. PNAS 98 14022-14026.

Yin XJ, Tani T, Yonemura I, Kawakami M, Miya-moto K, Hasegawa R, Kato Y \& Tsunoda Y 2002 Production of cloned pigs from adult somatic cells by chemically assisted removal of maternal chromosomes. Biology of Reproduction 67 442-446.

Zhang Y, Pan D, Sun X, Sun G, Wang X, Liu X, Li Y, Dai Y \& Li N 2006 Production of porcine cloned transgenic embryos expressing green fluorescent protein by somatic cell nuclear transfer. Science in China. Series C, Life Sciences 49 164-171.

Zheng YM, An ZX, Peng XR, Shi YQ \& Zhang Y 2006 EGFP expression in goat mammary epithelial cells. Chinese Journal of Agricultural Biotechnology 3 71-74.

Received 11 November 2008

First decision 27 January 2009

Accepted 4 March 2009 